\title{
Trade Openness and Youth Employment in Sub-Saharan Africa: Should We Regulate the Labor Market?
}

\author{
Koffi Kpognon ${ }^{1+}$, Henri Atangana Ondoa ${ }^{2}$, and Mamadou Bah ${ }^{1}$ \\ ${ }^{1}$ Pan African University, Cameroon \\ ${ }^{2}$ University of Yaoundé II, Cameroon
}

\begin{abstract}
This study analyzes the effect of trade openness and labor market regulation on youth employment in Sub-Saharan Africa (SSA). It covers a panel of 41 countries over the period 2002-2017, a period determined by the availability of the relevant data on labor market regulation. The results obtained using pooled ordinary least squares (OLS) regression and instrumental variable-two-stage least squares (IV-2SLS) estimators reveal that trade openness and labor market regulation rigidity have a positive and significant impact on youth employment in SSA. More interestingly, trade openness negatively and significantly affects youth employment in more rigid labor markets in SSA. This result remains robust in several robustness tests. Finally, this study also examined the case of young women's employment in SSA.
\end{abstract}

Keywords: Trade Openness, Labor market regulation, Youth Employment, Pooled ordinary least squares (OLS) regression, instrumental variable-two-stage least squares (IV-2SLS), Sub-Saharan Africa (SSA)

JEL Classifications: E24, F16, J08

Received 5 March 2020, Revised 18 September 2020, Accepted 22 October 2020

\section{Introduction}

International trade is a determinative factor in reducing poverty and inequality, specifically through its role in stimulating job creation. Nevertheless, in several developing countries, international trade can lead to the destruction of jobs or the creation of less decent jobs, particularly for young people and women. The relationship between trade openness and employment has been widely discussed. Since the theories of Hecksher-Ohlin-Stolper-Samuelson and Viner, there has been no consensus regarding the effect of trade openness on job creation. While several empirical studies (Matusz, 1996; Dutt et al., 2009; Iapadre, 2011; Kiyota, 2011; Felbermayr et al., 2011a, 2011b; Gozgor, 2014; Awad \& Youssof, 2017) have argued that trade liberalization

\footnotetext{
+Corresponding Author: Koffi Kpognon

Ph.D., Pan-African University - African Union Commission-Institute of Governance, Humanities and Social Sciences (PAUGHSS). Email: kkoffide7@gmail.com

Co-Author: Henri Atangana Ondoa

Lecturer, University of Yaoundé II, Cameroon. BP. 18 SOA, Cameroon. Email: atanganaondoa@yahoo.fr

Co-Author: Mamadou Bah

Ph.D., Pan-African University - African Union Commission-Institute of Governance, Humanities and Social Sciences (PAUGHSS), Consultant at African Development Bank Group (AfDB), Abidjan, Côte d'Ivoire. Email: bah_20042000@yahoo.fr
} 
would promote job creation, others have demonstrated that international trade contributes to increased unemployment (Helpman \& Itskhoki, 2007; Janiak, 2007). Some studies have shown that this increase in unemployment is found only among lower-skilled workers (Şener, 2001; Moore \& Ranjan, 2005).

The literature on the determinants of employment (or unemployment) has also relied on the role of labor market regulation. The objective of labor market regulation is to protect the most vulnerable participants in the labor market, generally by guaranteeing certain rights and providing workers with some basic protection against harm and/or loss of income. Botero et al. (2004) argued that every country in the world recognizes a complex system of laws and that institutions want to protect the interests of workers and ensure a minimum standard of living for their populations. These laws and institutions include employment laws that regulate individual employment contracts; collective or industrial relation laws that regulate the negotiation, adoption, and enforcement of collective agreements; laws that regulate the organization of trade unions; and laws that regulate industrial action by workers and employers (Botero et al., 2004). However, according to the World Bank (2007, p. 19), "laws created to protect workers are often detrimental to them." According to the empirical literature, the impact of these laws and institutions on labor market outcomes remains ambiguous (see, e.g., Scarpetta, 1996; Elmeskov et al., 1998; Nickell \& Layard, 1999; Acemoglu \& Shimer, 1999; Feldmann, 2003, 2005; Heckman Pagés, 2004; Bakeret et al., 2005; Nickell et al., 2005; Bassanini \& Duval, 2006; Rovelli \& Bruno, 2007; Flaig \& Rottmann, 2013; Nugent, 2016).

While the literature recognizes the role of trade liberalization and labor market regulation as determinants of employment (or unemployment), the impact of their interaction is also of interest to many researchers. The impact of international trade on the level of employment depends on the rigidity and friction of the labor market. A number of works can be cited in this regard, including Davis (1998), Davidson et al. (1999), Hasan (2001), Helpman and Itskhoki (2010), Kim (2011), Boulhol (2009, 2011), Moore and Ranjan (2005), Rodrik (2003), Goldberg and Pavnick (2003), Fugazza et al. (2014), Alexandre et al. (2017), Wang et al. (2018), and Selwaness and Zaki (2019). Selwaness and Zaki (2019) found that labor market rigidity reduces the positive impact of exports on employment for Middle East and North Africa (MENA) countries.

The literature on the impact of international trade on employment, particularly youth employment in Sub-Saharan Africa (SSA), is scarce. Three relatively recent studies linking international trade policies to youth employment (or unemployment) have focused on Africa-Anyanwu (2013), Anyanwu (2014), and Awad (2019). Anyanwu (2013) analyzed the macroeconomic determinants of youth unemployment for a sample of 48 African countries over the 1991-2009 period. Using the feasible generalized least squares (FGLS) technique, he found that foreign direct investment (FDI) tended to increase youth unemployment while openness tended to 
decrease youth unemployment in Africa. In his second study, Anyanwu (2014) empirically estimated the effect of Africa's intra-regional trade on youth unemployment for 46 African countries from 1980-2010. The results showed that a high level of intra-African trade reduced the aggregate of youth unemployment for both young women and men in Africa. Both studies failed to consider the effect of labor market regulation on youth unemployment. Yet, labor market regulations are likely to influence the labor market experiences of the youth more than they would those of other age groups. For example, because of their age, young people are typically new or relatively recent entrants to the labor market and are therefore more likely to be affected by employment protection legislation to the extent that it affects new employees. Similarly, they are likely to be overrepresented among low-paid workers and are thus more likely to be employed or seek employment in jobs directly affected by minimum wage legislation than other age groups are (O'Higgins \& Moscariello, 2017). Awad (2019) examined the impact of economic globalization on youth unemployment in 50 African countries between 1994 and 2013. He integrated labor market regulations into his control variables. Using the GMM Arellano-Bond $(\mathrm{AB})$ technique, he discovered that greater openness to global markets would result in lower youth unemployment. Moreover, rigid labor market regulation seemed to reduce the youth unemployment rate. However, his study did not consider the interaction between economic globalization and labor market regulation rigidity on youth unemployment. Moreover, it did not test the robustness of the results. The effect of trade openness or economic globalization on youth employment might indeed depend on its interaction with labor market regulation rigidity. In this study, we intend to address this gap in the literature by integrating the interaction between trade liberalization and labor market regulation in the analysis of the effect of trade policies on youth employment in Africa. There are other reasons why we are interested in SSA. SSA is home to the world's youngest population. Young people represent the future workforce of the region. Over the next decade, about 11 million young people will enter the labor market each year (World Bank, 2018). At the same time, the World Bank reveals that $60 \%$ of the unemployed in Africa are young. Moreover, when they are employed, the majority of young people are in the informal sector, where productivity is generally low. In its latest employment report, the International Labor Organization (ILO) (2018) reported that $94.9 \%$ of people between 15 and 24 years old in Africa work in the informal economy.

With respect to data on labor market regulation, according to the World Bank's Doing Business database, Africa has the highest number of labor regulations compared to other regions (African Economic Outlook, 2012; World Bank, 2012). In 2008, the average employment rigidity indicator for the SSA region was 47, while that of other world regions averaged lower than 32. In this paper, we attempt to determine whether this high rigidity is conducive to youth employment. The contribution of our study is threefold. First, unlike the three previous studies on youth employment in Africa, it integrates the interaction between trade openness and labor 
market regulation in its analysis. Second, it conducts several robustness tests to analyze the sensitivity of its results. Third, it focuses on the employment of young women in SSA, since young women are generally the most affected by unemployment in the region. Moreover, young women are more likely to work in the informal sector than young men are (AfDB, 2016). According to World Bank data, over the 2002-2017 period, the employment rate in SSA for young men was $48 \%$ while that of young women was $43 \%$. The study focuses on a panel of SSA countries and covers the 2002-2017 period, a period dictated by the availability of data on labor market regulation taken from the Fraser Institute's Economic Freedom of the World (EFW) index. We found that trade openness and rigid labor market regulation positively and significantly affected youth employment in SSA. More interestingly, we discovered that trade openness negatively and significantly affected youth employment in more rigid labor markets in SSA. This result remains robust to several tests of robustness. Finally, this study also examined young women's employment in SSA.

The rest of the work is structured as follows. In Section 2, we present a review of the literature on the relationship between trade openness, labor market regulation and employment (or unemployment). In Section 3, we present the main characteristics of our variables of interest and the link between them. Section 4 describes the methodology adopted and Section 5 presents the results obtained. Robustness tests are conducted in Section 6. Section 7 concludes.

\section{Literature Review}

The Heckscher-Ohlin-Samuelson (H-O) model followed by the sectoral model (Viner, 1931) was the primary attempt to determine the effect of trade on labor market outcomes, namely employment. The first argues that countries tend to export the good that intensively uses their relatively abundant production factor under free trade conditions. According to the StolperSamuelson effect, an increase in the relative price of a good (when a country has a comparative advantage) will lead to a more than proportional increase in real returns to the factor that is intensively used in the production of that good and, conversely, a decrease in real returns to other factors. Such effects are valid when it is assumed that factors are mobile between different sectors. The sectoral model (Viner, 1931) assumes that a factor of production is specific to a particular industry. A move toward free trade increases the price of exportable goods and reduces the price of importable goods. Thus, the performance of the factors used by the exporting sectors will increase while the factors used in the importing sectors will experience a decrease in revenue. According to this model, workers who move freely from one industry to another can win or lose since the real wage, in terms of exports, increases, while the real wage, in terms of imports, decreases. While factor-specificity treatments tend to generalize 
capital as immobile in the short run, even labor is unlikely to be as mobile as the standard $\mathrm{H}-\mathrm{O}$ model suggests. ${ }^{1)}$ This is because the theories developed in this model do not explicitly consider the state of labor market rigidity and the question of whether labor markets allow these theoretical potential effects to be realized. The labor market is often characterized by frictions that can influence the effect of international trade on the employment level. Fugazza et al. (2014) cited four reasons for the importance of considering friction in trade models. First, accounting for frictions enables trade to destroy or create jobs, rather than just removing the impact of trade on unemployment (or employment). Second, the impact of trade on unemployment (or employment) is likely to be complex and ambiguous. It is therefore important to understand when negative effects are expected to be dominant. Third, taking into account their context, welfare and unemployment are negatively correlated, but not perfectly: trade liberalization might destroy more jobs than it creates and nonetheless increase welfare. Fourth, this is an important policy issue, and policymakers are convinced that a link exists, even if they disagree on the direction of trade's impact on unemployment.

Davis (1998) is one of the first theoretical studies to analyze how the interaction between trade and labor market regulation rigidity can affect unemployment and employment. He argued that the opening up of international trade could significantly increase European unemployment because of Europe's commitment to maintaining the minimum wage. Based on the stylized model of the minimum wage in Europe and the flexible wage in the United States (US), he argued that the price of a product that reflects the European minimum wage defines the price of world trade. As trade begins, the US wage level will gradually increase to reach the European level, while the US can maintain zero unemployment because of its wage flexibility. It recognizes that Europe actually bears all of the costs of a trade shock, such as a sudden increase in imports from developing countries in the form of unemployment, while the US labor market is completely isolated because of European rigidity. Krugman (1995), on the other hand, acknowledged that trade seems to have reduced the relative wages of low-skilled workers in the US and the United Kingdom (UK), while in most European countries, trade seems to have increased unemployment. Differences in labor market institutions ${ }^{2}$ ) are highlighted as one of the main factors underlying the divergent effects of trade in these countries. Using data from 20 Organization for Economic Cooperation and Development (OECD) countries for 1961-2008, Kim (2011) found that increased trade led to higher aggregate unemployment because it interacted with rigid labor market institutions, whereas it would reduce aggregate unemployment if the labor market was characterized by flexibility. In a country with an average degree of labor market rigidity, an increase in trade has no significant effect on unemployment rates. Boulhol (2009) demonstrated that Davis' (1998) main idea could be generalized to a set of labor market institutions broader

1) This model assumes that workers are mobile between sectors.

2) In this study, we do not differentiate between labor market institutions and labor market regulations. 
than the simple setting of the minimum wage. Labor market institutions, such as the minimum wage, unemployment benefits, unionization rates, employment protection legislation, etc., can be seen as devices for raising wage costs at the bottom of the wage distribution. Labor market institutions influence labor costs and therefore the relative factors and prices of goods. As a result, imports from low-income economies are expected to be more likely to lead to higher unemployment. Using the two-factor matching framework of Pissarides (2000), the model developed by Boulhol (2011) emphasized that foreign labor market institutions affect a country's unemployment rate through trade. The main mechanism by which trading partners' institutions affect unemployment is simple. To the extent that labor market institutions are important for unemployment, they affect the cost of labor and thus the relative factors and prices of goods. It follows that labor market regulations contribute to establishing a comparative advantage in an open economy. Moore and Ranjan (2005) argued that an economy characterized by greater labor market rigidity would experience a larger quantitative effect of globalization on unemployment. Thus, these studies all argue that labor market institutions can amplify the increase in unemployment resulting from increased trade. $\left.{ }^{3}\right)$

On the other hand, Helpman and Itskhoki (2010) showed that lowering trade barriers might increase unemployment in a country with a relatively more flexible labor market, but it might also potentially reduce unemployment in a country with a relatively more flexible labor market. Unemployment increases in the more flexible country as workers are reassigned to the expanding sector in which labor market frictions are assumed higher. This might also be the case for a country with a more rigid labor market. However, if a country's labor market is very rigid, that country's trade sector will begin to contract rather than expand as trade increases. The result is a lower unemployment rate in the country with the more rigid labor market because workers are reallocated to the non-market sector, which is assumed to have no friction in the labor market.

Rodrik (2003) argued that trade makes the demand for labor more elastic and therefore less rigid. Less rigidity leads to larger shocks to employment and wages resulting from productivity or output demand shocks and thus increases employment volatility. This increase in elasticity also leads to the erosion of the bargaining power of labor relative to capital in profit-sharing and reduces the bargaining power of unions. Therefore, theoretical predictions about the link between trade, labor market rigidity, and labor market outcomes show that the effects of trade liberalization in a given country depend on the nature of labor market regulations. This is because trade liberalization is more likely to have a positive effect on employment and wages in countries with more flexible labor markets and vice versa (Goldberg \& Pavnick, 2003). In addition, more regulated labor markets tend to offer higher wages at the expense of employment in the sector as a whole. Wang et al. (2018) empirically examined whether the nature of firm-level

3) Moore and Ranjan (2005) defined labor market rigidity as any factor that tends to increase the reserve utility of workers. 
employment adjustment was affected by labor market flexibility and exposure to trade liberalization. Combining firm-level data with data on city-level hukou reform4) between 1998 and 2007, they found that firms responded to trade shocks by adjusting employment relatively more in the presence of hukou reform. Firms exposed to hukou reform had a higher employment adjustment rate on average than similar firms without the reform, indicating that the labor market reform led to greater employment adjustments. Fugazza et al. (2014) presented a new theoretical framework on trade and employment to assess the relationship between trade openness and unemployment. They showed that the impact of trade on unemployment depended on the covariance between comparative advantage and labor market frictions at the sectoral level. If the covariance was positive, trade liberalization might lead to an increase in unemployment, while if the correlation was negative, unemployment decreased as the economy opened up to international trade. This prediction was empirically confirmed on a panel of 97 countries over the 1995-2009 period. Selwaness and Zaki (2019) examined the interaction between export performance and labor market regulations on employment levels across a panel of MENA countries. They found that trade liberalization was more likely to have a positive impact on employment rates in countries with flexible labor markets and vice versa. They explained that rigid labor markets limited the ease of creating new jobs that met the increased demand for labor in expanding sectors when a country experienced an increase in exports.

\section{Data and Stylized Facts}

Our data covers a panel of 41 countries over the 2002-2017 period, a period dictated by the availability of data on labor market regulation. Table 1 presents the descriptive statistics of the study variables (excluding dummies) as well as the data sources. Figure 1 shows the correlation between trade openness and youth employment over the 2002-2017 period. For each variable, its time average was subtracted to eliminate fixed country effects. This figure intuitively demonstrates a positive relationship between trade openness and youth employment. What happens when we take into account the regulation of the labor market? With regard to Figure 2, we formed two groups of 10 countries. The first group (left) consists of the 10 SSA countries with the most flexible labor market regulation. The second group (right) consists of the 10 countries with the most rigid labor market regulation. Figure 2 clearly and unambiguously demonstrates the existence of a positive relationship between trade openness and youth employment

4) In 2001, hukou reform was launched in some Chinese cities to combat local labor market segregation. The Chinese labor market has always been very rigid, with a household registration system (or hukou system) separating the labor market into rural and urban sectors. The aim was to abolish the distinction between rural and urban types of hukou and encourage the movement of labor from rural to urban areas. To achieve this, local authorities in some cities took specific measures to reduce barriers to mobility and attract rural workers. 
in flexible labor markets and a negative relationship between trade openness and youth employment in rigid labor markets. It is this result that we will try to demonstrate through our empirical strategy. Throughout this paper, we show that this non-linear relationship is significant and robust given various specifications.

Table 1. Descriptive Statistics of Main Regression Variables (Excluding Dummies).

\begin{tabular}{lcccccc}
\hline \multicolumn{1}{c}{ Variable } & Obs. & Mean & Std. Dev. & Min & Max & Sources \\
\hline Youth Employment (\%) & 1,056 & 43.17961 & 17.47837 & 11.405 & 78.855 & WDI \\
Openness (\%) & 955 & 73.17437 & 37.12371 & 17.85861 & 311.3541 & WDI \\
LMR_rig & 592 & 3.948038 & 1.544712 & 0.761631 & 7.549445 & EFWD \\
Secondary Education Enrollment (Gross) & 625 & 40.48911 & 23.14424 & 5.21012 & 114.3809 & WDI \\
Real Per Capita GDP & 1,004 & 4223.069 & 5656.297 & 459.4265 & 40015.82 & WDI \\
Urban Population Share (\%) & 1,072 & 38.5076 & 16.66905 & 7.412 & 88.976 & WDI \\
Domestic Investment (\%) & 919 & 21.00147 & 9.11245 & -2.424358 & 74.60823 & WDI \\
Inflation_GDP Deflator & 1,004 & 18.73363 & 176.0695 & -31.56591 & 4800.532 & WDI \\
Size of Government & 629 & 6.345353 & 0.9951445 & 3.843691 & 9.441176 & WDI \\
Agriculture Added Value (\%) & 985 & 22.73901 & 14.60777 & 0.8926961 & 79.04236 & WDI \\
Tertiary Education Enrollment (Gross) & 558 & 6.636905 & 6.569839 & 0.21989 & 40.04368 & WDI \\
Tariffs & 642 & 6.50956 & 1.212571 & 0 & 9.490756 & WDI \\
Secondary Education Enrollment (Gross), Young women (\%) & 610 & 39.17229 & 26.11703 & 3.36119 & 115.3077 & WDI \\
Fertility Rate (\%) & 1,077 & 5.087709 & 1.274114 & 1.36 & 7.716 & WDI \\
\hline
\end{tabular}

(Source) The authors.

Figure 1. Cross-relationship between trade openness and youth employment (2002-2017 average).

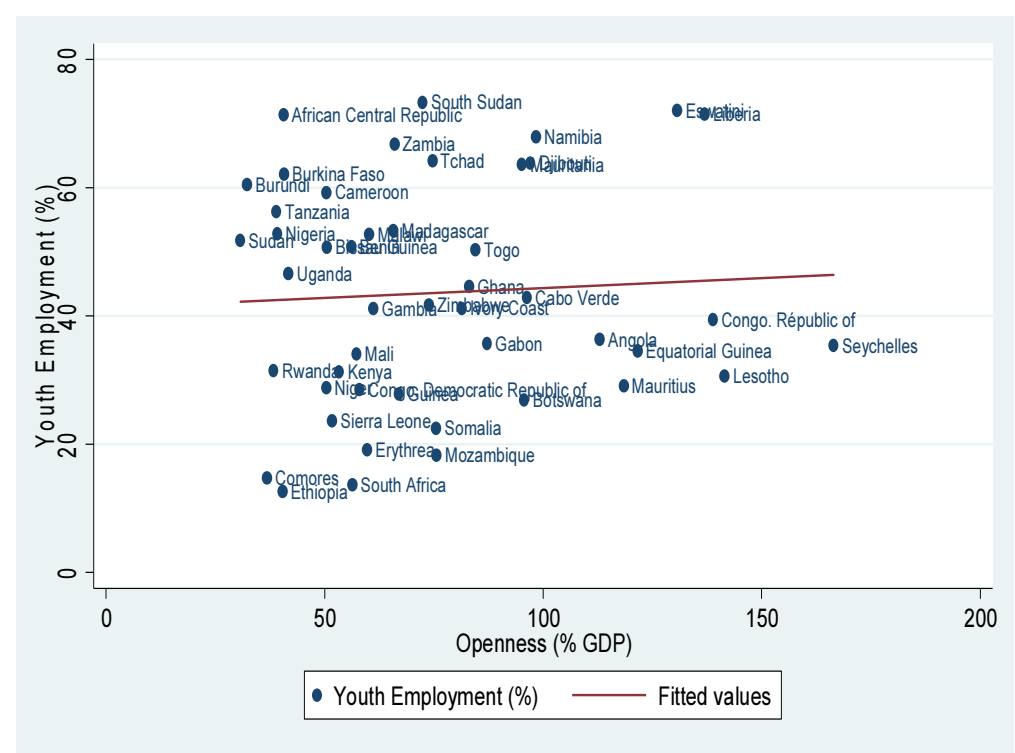


Figure 2. Cross-relationship between trade openness and youth employment in the 10 countries with flexible labor markets and the 10 countries with rigid labor markets (2002-2017 average).
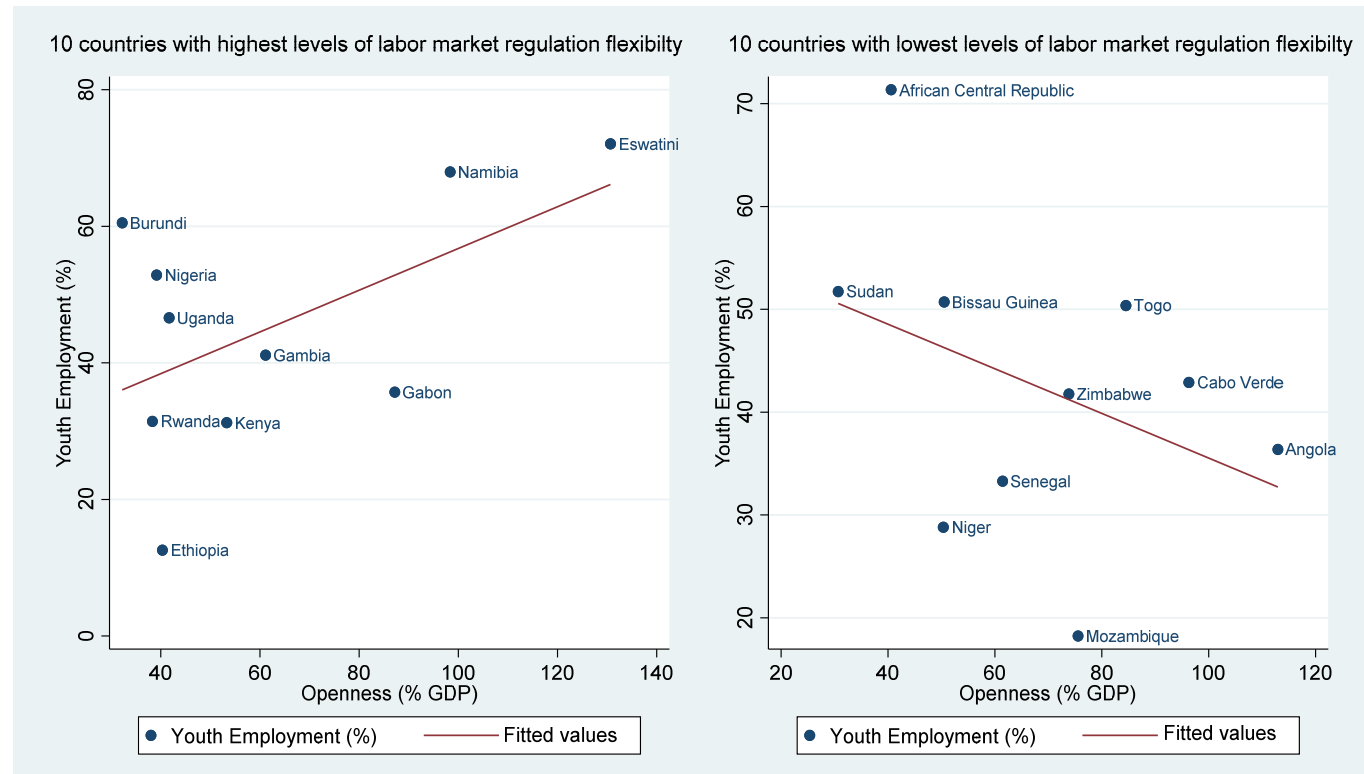

\section{Methodology: Econometric Specification, Variables, and Data Sources}

The following empirical model presents the relationship between youth employment, trade openness, and labor market regulation.

$$
\log (\text { Youth_empl })_{i t}=\alpha_{0}+\alpha_{1} \log (\text { Openness })_{i t}+\alpha_{2} L M R \_r i g_{i t}+\alpha_{3} X_{i t}+\mu_{i}+\pi_{t}+\varepsilon_{i t}
$$

Where Youth_empl, Openness and LMR_rig, respectively, represent youth employment, i.e., the employment-to-population ratio for persons aged 15-24, trade openness, i.e., the sum of exports and imports relative to gross domestic product (GDP), and the rigidity of labor market regulation (a composite index), which captures the rigidity of labor market regulation. For practical purposes, we posed $L M R_{\text {rig }}=10-L M R_{f l e x}$. $L M R_{\text {flex }}$ as a composite index consisting of six sub-indicators that measure the influence of hiring and minimum wage regulations, hiring and firing regulations, centralized collective bargaining, working hour regulations, mandatory costs of laying off workers, and conscription. It measures the flexibility of labor market regulation. It is derived from the Frazer Institute's EFW index and is normalized from 0 to 10 , with a higher value reflecting greater labor market regulation flexibility. Thus, $L M R_{\text {rig }}$ 
represents the rigidity of labor market regulation. It varies from 0 to 10 with a higher value reflecting greater rigidity of labor market regulation. The other two variables come from the World Bank. X represents a set of control variables that we selected from the empirical literature on the relationship between trade openness, labor market regulation, and youth employment. $\mu_{i}$ and $\pi_{t}$ represent country fixed effects and the time fixed effects, respectively, $\varepsilon_{i t}$ is the error term. The control variables include the following variables.

\section{A. Secondary education enrollment}

Secondary and higher education is relevant for reducing youth unemployment, at least more so than primary education, because it reinforces and expands the knowledge acquired at the primary level and provides essential skills for the labor market (Anyawu, 2014). Moreover, it has a greater potential to help people find a job or even create one themselves. However, it should be noted that many young graduates seeking employment in SSA are more interested in the public rather than the private sector. The public sector is sometimes unable to absorb the new labor entrants because of the recent adoption of market-oriented policies by countries. Its effect is therefore ambiguous.

\section{B. Real per capita GDP}

The variables related to national production such as GDP, GDP per capita, and the output gap influence the level of employment in a country according to Okun's Law (1962). Okun found that a $2.5 \%$ increase in the GDP growth rate lagging behind the standard rate was expected to lower the current $1 \%$ unemployment rate for the US economy. Real per capita GDP should therefore positively affect youth employment.

\section{Urban population share}

Urbanization is associated with increased consumption and changing consumption patterns. Urban populations are buying more manufactured goods. Even food products are bought and consumed differently, with the gradual predominance of processed and packaged foods sold in supermarkets, to the detriment of foods consumed or sold without processing (UNECA, 2017). For example, in Eastern and Southern Africa, modern retail trade (e.g., supermarkets) accounted for $5 \%-15 \%$ of the market for food purchased in 2010. This volume is expected to increase to $30 \%-40 \%$ by 2040 (Tschirley et al., 2013). New urban demand increases imports or, if guided by the appropriate policy framework, supports domestic value chains and job creation for the youth. Urbanization should therefore positively affect youth employment. 


\section{Domestic investment}

Theoretically, domestic investment positively influences the level of employment provided that it is labor-intensive. Low levels of domestic investment result in lower productive capacity, which leads to fewer opportunities for the poor to improve their livelihoods and lower rates of job creation. When directed toward capital-intensive sectors, domestic investment negatively affects employment. The theoretical effect is therefore ambiguous.

\section{E. Inflation (GDP deflator)}

Inflation is included to control for the effect of monetary policy variables. Countries with high inflation have unstable exchange rates. This is why they establish high trade barriers to protect their domestic industries from exchange rate uncertainty. Moreover, in the short term, the inflation rate is correlated with unemployment and thus with employment through the Philips curve mechanism. The effect is therefore ambiguous.

\section{F. The size of the government}

Government size can influence trade openness, particularly through tariffs, which are a source of fiscal revenue for the government, but also through other trade policy instruments. These instruments are sources of government revenue that can be used to finance active labor market policies, as is the case in welfare states (Madanizadeh \& Pilvar, 2019). A positive effect on youth employment is therefore expected.

\section{G. Agricultural value-added}

Several developing countries, particularly in SSA, have economies that rely primarily on the agricultural sector. Many of the goods exported by these countries are goods from the agricultural sector. In addition, the agricultural sector can benefit from inputs (e.g., technological goods) that are imported from outside to boost agricultural production. Finally, as poor countries depend largely on agricultural production, this sector benefits from several exceptions in trade agreements under the supervision of the Word Trade Organization (WTO). Agricultural value-added can therefore be correlated with trade openness, but also influence the level of employment to the extent that the agricultural sector is labor-intensive in SSA countries. Thus, we insert the share of the agricultural sector's value-added in GDP to control for the effect of the agricultural sector. Its effect on youth employment should be positive.

We believe that Model (1), which describes the relationship between youth employment on the one hand and trade openness and labor market regulation on the other, is not appropriate. 
Indeed, this model does not take into account labor adjustments when the economy is affected by labor market rigidity and exposure to trade liberalization. In their analysis of the effect of exports on employment in the MENA region, Selwaness and Zaki (2019) found that export-intensive countries experienced higher levels of employment (see Table 2 and Specifications 3, 4, and 5). However, they specified that this effect was only valid when the interaction term between exports and labor market rigidity was included in the regression. To account for this effect in this study, like Selwaness and Zaki (2019), we introduce an interaction term between trade openness and labor market rigidity into Model (1). Our new empirical model is as follows:

$$
\begin{aligned}
\log (\text { Youth_empl })_{i t}= & \alpha_{0}+\alpha_{1} \ln (\text { Openness })_{i t}+\alpha_{2} L M R \_r i g_{i t} \\
& +\alpha_{3} \log (\text { Opennes })^{*} L M R \_r i g_{i t}+\alpha_{4} X_{i t}+\mu_{i}+\pi_{t}+\varepsilon
\end{aligned}
$$

Our empirical strategy is to first estimate Model (2) using the pooled ordinary least squares (OLS) estimator. Then, we use the instrumental variable-two-stage least squares (IV-2SLS) estimator to take into account the potential endogeneity linked to labor market regulations (or labor market institutions) but also to trade openness according to Felbermayr et al. (2009) and Klein and Weirowski (2011). Hansen's J statistic and the Cragg-Donald Wald F and Kleibergen-Paaprk Wald F statistics are used to ensure the validity of the instruments (i.e., the lagged levels of the endogenous variables). The p-value of the Kleibergen and Papp (2006) LM statistics is also used for the under-identification test.

\section{Empirical Results}

In Table 2, the results of estimating Equation (2) reveal that trade openness positively and significantly affects youth employment in SSA with a coefficient ranging from 0.230 to 0.674 (Specifications 1-5). Increasing trade openness by $1 \%$ leads to an increase in the youth employment rate of between $0.23 \%$ and $0.674 \%$. This result is consistent with the World Bank's (2009) argument that the expansion of world trade has shifted production around the world. Since young people are the most sensitive to the growing demand for labor, these changes might favor them. Young people might also be particularly attractive to firms in new and expanding sectors because they are more adaptable than older workers (Awad, 2019). Our result is similar to that found by Anyanwu (2014) - higher levels of intra-African trade reduced overall, female, and male youth unemployment in Africa. Similarly, Awad (2019) showed that greater openness to global markets would result in lower youth unemployment. His study covered 50 African countries between 1994 and 2013. Our results suggest that stricter labor market regulations are favorable to youth employment in SSA. The effect of labor market rigidity is positive and statistically 
Table 2. Panel Regression of Youth Employment on Trade Openness and Labor Market Regulation (Pooled OLS Results with Fixed Effects).

\begin{tabular}{|c|c|c|c|c|c|}
\hline \multicolumn{6}{|c|}{ Dependent Variable: log (Youth Employment) } \\
\hline Variable & (1) & (2) & (3) & (4) & $(5)$ \\
\hline \multirow[t]{2}{*}{$\log ($ Openness $)$} & $0.230 * *$ & $0.647 * * *$ & $0.648 * * *$ & $0.674 * * *$ & $0.653 * * *$ \\
\hline & $(0.105)$ & $(0.132)$ & $(0.132)$ & $(0.133)$ & $(0.133)$ \\
\hline \multirow[t]{2}{*}{ LMR_rig } & $0.211^{*}$ & $0.346^{* *}$ & $0.339 * *$ & $0.357 * * *$ & $0.313^{* *}$ \\
\hline & $(0.112)$ & $(0.137)$ & $(0.136)$ & $(0.135)$ & $(0.136)$ \\
\hline \multirow[t]{2}{*}{$\log ($ Openness $) *$ LMR_rig } & $-0.0748 * * *$ & $-0.115^{* * *}$ & $-0.115 * * *$ & $-0.119 * * *$ & $-0.109 * * *$ \\
\hline & $(0.0280)$ & $(0.0352)$ & $(0.0348)$ & $(0.0346)$ & $(0.0346)$ \\
\hline \multirow[t]{2}{*}{ Secondary Education Enrollment (Gross) } & $-0.0101 * * *$ & $-0.0172 * * *$ & $-0.0170 * * *$ & $-0.0173 * * *$ & $-0.0164 * * *$ \\
\hline & $(0.00129)$ & $(0.00191)$ & $(0.00188)$ & $(0.00189)$ & $(0.00210)$ \\
\hline \multirow[t]{2}{*}{$\log$ (Real Per Capita GDP) } & $0.0624 *$ & 0.0649 & 0.0522 & 0.0543 & $0.0708^{*}$ \\
\hline & $(0.0372)$ & $(0.0439)$ & $(0.0424)$ & $(0.0416)$ & $(0.0384)$ \\
\hline \multirow[t]{2}{*}{$\log ($ Urban Population Share $)$} & $0.215^{* * *}$ & $0.329 * * *$ & $0.333 * * *$ & $0.343 * * *$ & $0.336 * * *$ \\
\hline & $(0.0528)$ & $(0.0552)$ & $(0.0551)$ & $(0.0556)$ & $(0.0573)$ \\
\hline \multirow[t]{2}{*}{ Domestic Investisment } & & $-0.00747 * *$ & $-0.00786^{* *}$ & $-0.00721 * *$ & $-0.00720 * *$ \\
\hline & & $(0.00343)$ & $(0.00345)$ & $(0.00343)$ & $(0.00343)$ \\
\hline \multirow[t]{2}{*}{ Inflation, GDP deflator } & & & -0.00256 & -0.00261 & -0.00282 \\
\hline & & & $(0.00225)$ & $(0.00235)$ & $(0.00239)$ \\
\hline \multirow[t]{2}{*}{ Size Of Government } & & & & $0.0618^{* * *}$ & $0.0571 * * *$ \\
\hline & & & & $(0.0190)$ & $(0.0194)$ \\
\hline \multirow[t]{2}{*}{ Agriculture Added Value (\%) } & & & & & 0.00313 \\
\hline & & & & & $(0.00261)$ \\
\hline \multirow[t]{2}{*}{ Constant } & $2.337 * * *$ & 0.718 & 0.836 & 0.274 & 0.181 \\
\hline & $(0.503)$ & $(0.582)$ & $(0.573)$ & $(0.617)$ & $(0.625)$ \\
\hline Country Fixed Effects & Yes & Yes & Yes & Yes & Yes \\
\hline Time Fixed Effects & Yest & Yes & Yes & Yes & Yes \\
\hline Observations & 350 & 348 & 348 & 348 & 346 \\
\hline R-squared & 0.439 & 0.396 & 0.400 & 0.417 & 0.416 \\
\hline F-statistic & 195.6 & 22 & 20.01 & 18.94 & 17.94 \\
\hline Prob $\mathrm{F}>0$ & 0 & 0 & 0 & 0 & 0 \\
\hline
\end{tabular}

(Source) The authors.

Note. Values in brackets represent robust standard deviations; ***, **, ${ }^{*}$ mean significant at a $1 \%, 5 \%$, and $10 \%$ level, respectively.

significant. Similar results were found by Awad (2019). Similarly, Selwaness and Zaki (2019) found a positive and significant effect of labor market rigidity on the employment-to-population ratio in the MENA region. Regarding the interactive term between trade openness and labor market rigidity, it should be noted that we found a significant negative effect on youth employment. This result is interesting since it suggests that trade openness negatively and significantly affects youth employment in more rigid labor markets in SSA (see Figure 3). Selwaness and Zaki (2019) found similar results in the MENA region. 
Figure 3. Marginal effect of trade openness on youth employment for different levels of labor market regulation rigidity.

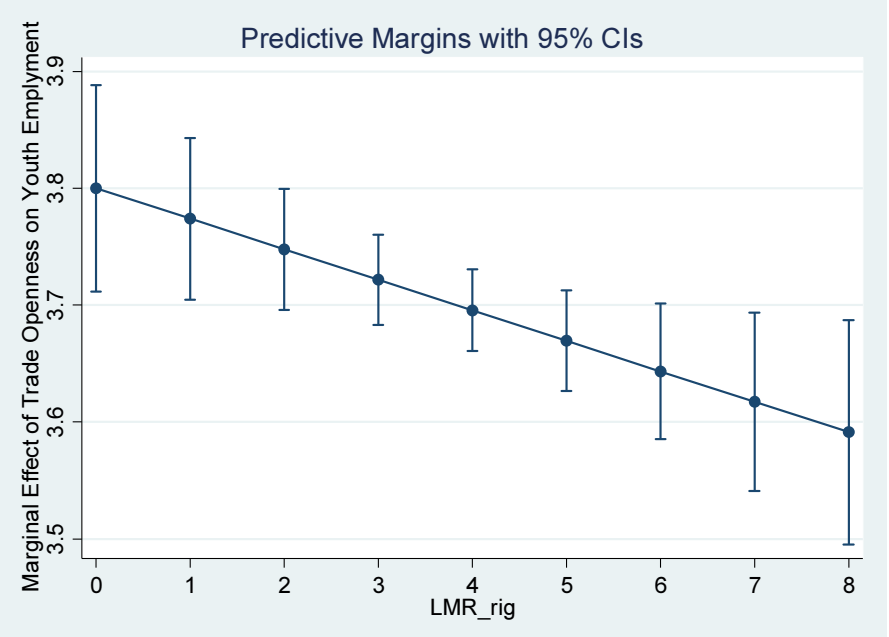

For the control variables, we found that secondary education enrollment has a significant negative effect on the employment-to-population ratio for 15-24 year-olds, suggesting that labor markets in most SSA countries are unable to create sufficient jobs, especially decent jobs, for young newcomers who are increasingly educated. Anyanwu (2014), on the other hand, found a significant negative effect of secondary education on youth unemployment in Africa. GDP per capita has a positive and significant effect on the employment-to-population ratio for persons aged 15-24 years (Specifications 1 and 5) as well as the urban population share and the size of the government. On the other hand, domestic investment has a negative and significant effect on youth employment. Agricultural value-added and inflation are not significant.

Table 3 presents the results obtained with the IV-2SLS estimator. First of all, we note the rejection of the null hypothesis of under-identification since the p-values of Kleibergen and Papp (2006) were null for all specifications. Our model is thus just identified. Then, when we compare the values of the Cragg-Donald Wald F and Kleibergen-Paap Wald F statistics to the critical values of Stock and Yogo (2005) to determine the IV bias and test size distortions, we reject the weak instrument null hypothesis since the values of the statistics are greater than the critical ones of Stock and Yogo (2005). Our instruments are therefore valid. This result is confirmed by the Hansen's statistic and p-value, which is greater than $10 \%$ for all specifications. As for the results of the estimates of our key variables, they are similar to the initial results. 
Table 3. Panel Regression of Youth Employment on Trade Openness and Labor Market Regulation (IV with Results with Fixed Effects).

\begin{tabular}{|c|c|c|c|c|c|}
\hline \multicolumn{6}{|c|}{ Dependent Variable : $\log$ (Youth Employment) } \\
\hline Variable & (1) & (2) & (3) & (4) & (5) \\
\hline \multirow[t]{2}{*}{$\log ($ Openness $)$} & $0.748 * * *$ & $0.836 * * *$ & $0.841 * * *$ & $0.887 * * *$ & $0.864 * * *$ \\
\hline & $(0.170)$ & $(0.167)$ & $(0.167)$ & $(0.172)$ & $(0.170)$ \\
\hline \multirow[t]{2}{*}{ LMR_rig } & $0.415^{* *}$ & $0.414 * *$ & $0.413^{* *}$ & $0.443 * *$ & $0.392 * *$ \\
\hline & $(0.173)$ & $(0.168)$ & $(0.169)$ & $(0.173)$ & $(0.173)$ \\
\hline \multirow[t]{2}{*}{$\log ($ Openness $) *$ LMR_rig } & $-0.140 * * *$ & $-0.142 * * *$ & $-0.142 * * *$ & $-0.150 * * *$ & $-0.138 * * *$ \\
\hline & $(0.0441)$ & $(0.0433)$ & $(0.0432)$ & $(0.0442)$ & $(0.0441)$ \\
\hline \multirow[t]{2}{*}{ Secondary Education Enrollment (Gross) } & $-0.0150 * * *$ & $-0.0175^{* * *}$ & $-0.0174 * * *$ & $-0.0178 * * *$ & $-0.0165 * * *$ \\
\hline & $(0.00155)$ & $(0.00191)$ & $(0.00191)$ & $(0.00194)$ & $(0.00218)$ \\
\hline \multirow[t]{2}{*}{$\log ($ Real Per Capita GDP) } & -0.0404 & -0.00912 & -0.0137 & -0.0170 & 0.000332 \\
\hline & $(0.0473)$ & $(0.0481)$ & $(0.0479)$ & $(0.0463)$ & $(0.0426)$ \\
\hline \multirow[t]{2}{*}{$\log ($ Urban Population Share $)$} & $0.365 * * *$ & $0.376^{* * *}$ & $0.378 * * *$ & $0.405 * * *$ & $0.404 * * *$ \\
\hline & $(0.0634)$ & $(0.0590)$ & $(0.0591)$ & $(0.0604)$ & $(0.0633)$ \\
\hline \multirow[t]{2}{*}{ Domestic Investisment } & & $-0.00885^{* *}$ & $-0.00908 * *$ & $-0.00808^{* *}$ & $-0.00819 * *$ \\
\hline & & $(0.00344)$ & $(0.00353)$ & $(0.00347)$ & $(0.00352)$ \\
\hline \multirow[t]{2}{*}{ Inflation, GDP deflator } & & & -0.000885 & -0.00122 & -0.00149 \\
\hline & & & $(0.00189)$ & $(0.00219)$ & $(0.00218)$ \\
\hline \multirow[t]{2}{*}{ Size Of Government } & & & & $0.0711 * * *$ & $0.0635 * * *$ \\
\hline & & & & $(0.0213)$ & $(0.0211)$ \\
\hline \multirow[t]{2}{*}{ Agriculture Added Value (\%) } & & & & & 0.00463 \\
\hline & & & & & $(0.00299)$ \\
\hline \multirow[t]{2}{*}{ Constant } & 0.874 & 0.553 & 0.577 & -0.135 & -0.274 \\
\hline & $(0.692)$ & $(0.676)$ & $(0.680)$ & $(0.749)$ & $(0.752)$ \\
\hline Country Fixed Effects & Yes & Yes & Yes & Yes & Yes \\
\hline Time Fixed Effects & Yest & Yes & Yes & Yes & Yes \\
\hline Observations & 295 & 293 & 293 & 293 & 292 \\
\hline R-squared & 0.410 & 0.440 & 0.440 & 0.461 & 0.465 \\
\hline Underindentification Test (Kleibergen-Paap Rk LM Statistic) & 34.83 & 37.98 & 38.61 & 37.93 & 39.14 \\
\hline Prob $>$ LM & 0 & 0 & 0 & 0 & 0 \\
\hline Weak Identification Test (Cragg-Donald Wald F Stat) & 209.1 & 186.8 & 186.1 & 184.5 & 178.8 \\
\hline Weak Identification Test(Kleibergen-Paap Rk Wald F Stat) & 101 & 82.17 & 81.50 & 79.03 & 77.67 \\
\hline Hansen_stat & 1.408 & 1.164 & 1.040 & 2.114 & 0.517 \\
\hline Hansen P_value & 0.495 & 0.559 & 0.595 & 0.347 & 0.772 \\
\hline \multicolumn{6}{|l|}{ Stock-Yogo weak ID test critical values: } \\
\hline 5\% Maximal IV Relative Bias & 9.53 & 9.53 & 9.53 & 9.53 & 9.53 \\
\hline 10\% Maximal IV Relative Bias & 6.61 & 6.61 & 6.61 & 6.61 & 6.61 \\
\hline 20\% Maximal IV Relative Bias & 4.99 & 4.99 & 4.99 & 4.99 & 4.99 \\
\hline 30\% Maximal IV Relative Bias & 4.30 & 4.30 & 4.30 & 4.30 & 4.30 \\
\hline
\end{tabular}

(Source) The authors.

Note. Values in brackets represent robust standard deviations; ***,**, mean significant at a $1 \%, 5 \%$, and $10 \%$ level, respectively. 


\section{Robustness Checks}

To validate and test our main results, i.e., the effect of trade openness, the rigidity of labor market regulation, and their interaction, we performed a battery of robustness checks. In the first step, like Selwaness and Zaki (2019), we replaced the secondary education enrollment rate with that of tertiary education (Table 4). Second, we replaced trade openness measured as the sum of exports and imports relative to GDP (\%) with tariffs. Madanizadeh and Pilvar (2019) also used the tariff rate from World Integrated Trade Solution (TRAINS) and Clemens and Williamson (2004) to measure trade openness and found that trade openness increased the rate of labor force participation. In our case, we use tariffs data from the Fraser Institute's EFW index. It is a composite index consisting of revenues from trade taxes, the mean tariff rate, and the standard deviation of tariff rates. Tariffs are normalized from 0 to 10 , with a higher value reflecting very low tariffs. The results are presented in Table 5. Finally, we used external instruments to correct for endogeneity related to the variables trade openness and labor market regulation (or labor market institutions). These are Frankel and Romer's (1999) measures of trade openness, the landlockedness (which takes the value of 1 if the country is landlocked and 0 otherwise), legal origin, religion, and latitude. Following Gozgor (2017), we use the Frankel and Romer (1999) measure and the landlockedness variable to correct for the endogeneity associated with trade openness. The variables of legal origin, religion, and latitude are used, in accordance with Acemoglu et al. (2005), to correct for the endogeneity related to labor market institutions (see Table 6). The three exogenous variables are taken from La Porta et al. (1999). Similar results are valid for all three specifications. While trade openness and rigidity are always associated with a positive and significant effect on youth employment, separately, their interaction is negative and statistically significant. 
Table 4. Panel Regression of Youth Employment on Trade Openness and Labor Market Regulation (IV with Results with Fixed Effects) with Tertiary Education Enrollment.

\begin{tabular}{|c|c|c|c|c|c|}
\hline \multicolumn{6}{|c|}{ Dependent Variable : $\log$ (Youth Employment) } \\
\hline Variable & (1) & (2) & (3) & (4) & (5) \\
\hline \multirow[t]{2}{*}{$\log ($ Openness $)$} & $0.620 * * *$ & $0.684 * * *$ & $0.686 * * *$ & $0.718 * * *$ & $0.700 * * *$ \\
\hline & $(0.213)$ & $(0.216)$ & $(0.218)$ & $(0.216)$ & $(0.214)$ \\
\hline \multirow[t]{2}{*}{ LMR_rig } & $0.536^{* * *}$ & $0.620 * * *$ & $0.621 * * *$ & $0.638 * * *$ & $0.535 * * *$ \\
\hline & $(0.160)$ & $(0.165)$ & $(0.165)$ & $(0.169)$ & $(0.170)$ \\
\hline \multirow[t]{2}{*}{$\log ($ Openness $) *$ LMR_rig } & $-0.158 * * *$ & $-0.180 * * *$ & $-0.180 * * *$ & $-0.183 * * *$ & $-0.161 * * *$ \\
\hline & $(0.0421)$ & $(0.0434)$ & $(0.0435)$ & $(0.0441)$ & $(0.0442)$ \\
\hline \multirow[t]{2}{*}{ InsTert } & $-0.0262 * * *$ & $-0.0262 * * *$ & $-0.0262 * * *$ & $-0.0303 * * *$ & $-0.0289 * * *$ \\
\hline & $(0.00402)$ & $(0.00426)$ & $(0.00428)$ & $(0.00431)$ & $(0.00432)$ \\
\hline \multirow[t]{2}{*}{$\log ($ Real Per Capita GDP $)$} & $-0.139 *$ & $-0.159 * *$ & $-0.160 * *$ & $-0.146^{* *}$ & -0.0877 \\
\hline & $(0.0757)$ & $(0.0763)$ & $(0.0765)$ & $(0.0710)$ & $(0.0650)$ \\
\hline \multirow[t]{2}{*}{$\log ($ Urban Population Share $)$} & $0.364 * * *$ & $0.370 * * *$ & $0.370 * * *$ & $0.418 * * *$ & $0.441 * * *$ \\
\hline & $(0.0667)$ & $(0.0685)$ & $(0.0686)$ & $(0.0694)$ & $(0.0714)$ \\
\hline \multirow[t]{2}{*}{ Domestic Investisment } & & 0.00379 & 0.00374 & $0.00536^{*}$ & 0.00467 \\
\hline & & $(0.00292)$ & $(0.00294)$ & $(0.00285)$ & $(0.00285)$ \\
\hline \multirow[t]{2}{*}{ Inflation, GDP deflator } & & & -0.000250 & -0.000836 & -0.00138 \\
\hline & & & $(0.00152)$ & $(0.00193)$ & $(0.00197)$ \\
\hline \multirow[t]{2}{*}{ Size Of Government } & & & & $0.0940 * * *$ & $0.0870 * * *$ \\
\hline & & & & $(0.0210)$ & $(0.0210)$ \\
\hline \multirow[t]{2}{*}{ Agriculture Added Value (\%) } & & & & & $0.00868 * * *$ \\
\hline & & & & & $(0.00297)$ \\
\hline \multirow[t]{2}{*}{ Constant } & $1.602 * *$ & $1.398^{* *}$ & $1.399 * *$ & 0.371 & -0.198 \\
\hline & $(0.618)$ & $(0.632)$ & $(0.634)$ & $(0.722)$ & $(0.768)$ \\
\hline Country Fixed Effects & Yes & Yes & Yes & Yes & Yes \\
\hline Time Fixed Effects & Yest & Yes & Yes & Yes & Yes \\
\hline Observations & 287 & 285 & 285 & 285 & 282 \\
\hline R-squared & 0.319 & 0.335 & 0.335 & 0.383 & 0.395 \\
\hline Underindentification Test (Kleibergen-Paap Rk LM Statistic) & 77.53 & 74.85 & 73.13 & 73.80 & 77.78 \\
\hline Prob $>$ LM & 0 & 0 & 0 & 0 & 0 \\
\hline Weak Identification Test (Cragg-Donald Wald F Stat) & 198.3 & 190.2 & 208.7 & 207.3 & 200.2 \\
\hline Weak Identification Test(Kleibergen-Paap Rk Wald F Stat) & 153.5 & 145.2 & 192.8 & 185.4 & 208.1 \\
\hline Hansen_stat & 1.104 & 1.198 & 1.188 & 1.956 & 1.742 \\
\hline Hansen $P_{-}$value & 0.576 & 0.549 & 0.552 & 0.376 & 0.419 \\
\hline \multicolumn{6}{|l|}{ Stock-Yogo weak ID test critical values: } \\
\hline 5\% Maximal IV Relative Bias & 9.53 & 9.53 & 9.53 & 9.53 & 9.53 \\
\hline 10\% Maximal IV Relative Bias & 6.61 & 6.61 & 6.61 & 6.61 & 6.61 \\
\hline 20\% Maximal IV Relative Bias & 4.99 & 4.99 & 4.99 & 4.99 & 4.99 \\
\hline $30 \%$ Maximal IV Relative Bias & 4.30 & 4.30 & 4.30 & 4.30 & 4.30 \\
\hline
\end{tabular}

(Source) The authors.

Note. Values in brackets represent robust standard deviations; ${ }^{* *},{ }^{* *},{ }^{*}$ mean significant at a $1 \%, 5 \%$, and $10 \%$ level, respectively. 
Table 5. Panel Regression of Youth Employment on Trade Openness and Labor Market Regulation (IV with Results with Fixed Effects) with Tariffs.

\begin{tabular}{|c|c|c|c|c|c|}
\hline \multicolumn{6}{|c|}{ Dependent Variable: $\log$ (Youth Employment) } \\
\hline Variable & (1) & (2) & (3) & (4) & (5) \\
\hline \multirow[t]{2}{*}{$\log$ (tariffs) } & $1.113^{* * *}$ & $0.784 * *$ & $0.727 * *$ & $0.583 *$ & 0.564 \\
\hline & $(0.383)$ & $(0.348)$ & $(0.343)$ & $(0.348)$ & $(0.380)$ \\
\hline \multirow[t]{2}{*}{ LMR_rig } & $0.629 * * *$ & $0.481 * * *$ & $0.456 * *$ & $0.407 * *$ & $0.413 * *$ \\
\hline & $(0.193)$ & $(0.179)$ & $(0.176)$ & $(0.178)$ & $(0.180)$ \\
\hline \multirow[t]{2}{*}{$\log$ (tariffs)*LMR_rig } & $-0.391 * * *$ & $-0.319 * * *$ & $-0.309 * * *$ & $-0.285 * * *$ & $-0.289 * * *$ \\
\hline & $(0.1000)$ & $(0.0932)$ & $(0.0920)$ & $(0.0922)$ & $(0.0930)$ \\
\hline \multirow{2}{*}{ Secondary Education Enrollment (Gross) } & $-0.0163 * * *$ & $-0.0167 * * *$ & $-0.0165 * * *$ & $-0.0165 * * *$ & $-0.0154 * * *$ \\
\hline & $(0.00164)$ & $(0.00178)$ & $(0.00174)$ & $(0.00178)$ & $(0.00230)$ \\
\hline \multirow[t]{2}{*}{$\log ($ Real Per Capita GDP $)$} & 0.0199 & 0.0199 & 0.00595 & 0.00152 & 0.0109 \\
\hline & $(0.0486)$ & $(0.0507)$ & $(0.0478)$ & $(0.0481)$ & $(0.0458)$ \\
\hline \multirow[t]{2}{*}{$\log ($ Urban Population Share $)$} & $0.529 * * *$ & $0.483^{* * *}$ & $0.492 * * *$ & $0.514 * * *$ & $0.529 * * *$ \\
\hline & $(0.0637)$ & $(0.0594)$ & $(0.0604)$ & $(0.0633)$ & $(0.0701)$ \\
\hline \multirow[t]{2}{*}{ Domestic Investisment } & & -0.00522 & $-0.00572 *$ & -0.00396 & -0.00394 \\
\hline & & $(0.00335)$ & $(0.00342)$ & $(0.00357)$ & $(0.00373)$ \\
\hline \multirow[t]{2}{*}{ Inflation, GDP deflator } & & & -0.00359 & $-0.00446^{*}$ & $-0.00484^{*}$ \\
\hline & & & $(0.00245)$ & $(0.00250)$ & $(0.00248)$ \\
\hline \multirow[t]{2}{*}{ Size Of Government } & & & & $0.0750 * * *$ & $0.0699 * * *$ \\
\hline & & & & $(0.0215)$ & $(0.0226)$ \\
\hline \multirow[t]{2}{*}{ Agriculture Added Value (\%) } & & & & & 0.00377 \\
\hline & & & & & $(0.00316)$ \\
\hline \multirow[t]{2}{*}{ Constant } & 0.635 & $1.609 *$ & $1.849 * *$ & $1.569 * *$ & 1.390 \\
\hline & $(0.938)$ & $(0.836)$ & $(0.800)$ & $(0.782)$ & $(0.879)$ \\
\hline Country Fixed Effects & Yes & Yes & Yes & Yes & Yes \\
\hline Time Fixed Effects & Yest & Yes & Yes & Yes & Yes \\
\hline Observations & 275 & 270 & 270 & 270 & 270 \\
\hline R-squared & 0.430 & 0.469 & 0.473 & 0.495 & 0.499 \\
\hline Underindentification Test (Kleibergen-Paap Rk LM Statistic) & 18.43 & 19.92 & 20.33 & 21.17 & 24.02 \\
\hline Prob $>$ LM & 0.00245 & 0.00129 & 0.00108 & 0.000752 & 0.000215 \\
\hline Weak Identification Test (Cragg-Donald Wald F Stat) & 69.41 & 66.40 & 65.82 & 65.06 & 63.91 \\
\hline Weak Identification Test(Kleibergen-Paap Rk Wald F Stat) & 31.83 & 31.76 & 32.70 & 32.85 & 33.81 \\
\hline Hansen_stat & 4.204 & 4.596 & 4.022 & 2.964 & 3.036 \\
\hline Hansen $\mathrm{P}_{\text {_value }}$ & 0.379 & 0.331 & 0.403 & 0.564 & 0.552 \\
\hline \multicolumn{6}{|l|}{ Stock-Yogo weak ID test critical values: } \\
\hline 5\% Maximal IV Relative Bias & 13.95 & 13.95 & 13.95 & 13.95 & 13.95 \\
\hline 10\% Maximal IV Relative Bias & 8.50 & 8.50 & 8.50 & 8.50 & 8.50 \\
\hline 20\% Maximal IV Relative Bias & 5.56 & 5.56 & 5.56 & 5.56 & 5.56 \\
\hline 30\% Maximal IV Relative Bias & 4.44 & 4.44 & 4.44 & 4.44 & 4.44 \\
\hline
\end{tabular}

(Source) The authors.

Note. Values in brackets represent robust standard deviations; ${ }^{* *},{ }^{* *},{ }^{*}$ mean significant at a $1 \%, 5 \%$, and $10 \%$ level, respectively. 
Table 6. Panel Regression of Youth Employment on Trade Openness and Labor Market Regulation (IV with Results with Fixed Effects) with External Instruments.

\begin{tabular}{|c|c|c|c|c|c|}
\hline \multicolumn{6}{|c|}{ Dependent Variable: $\log ($ Youth Employment) } \\
\hline Variable & (1) & (2) & (3) & (4) & (5) \\
\hline \multirow[t]{2}{*}{$\log ($ Openness $)$} & $1.753 * * *$ & $1.722 * * *$ & $1.705 * * *$ & $1.945 * * *$ & $1.845^{* * *}$ \\
\hline & $(0.388)$ & $(0.344)$ & $(0.345)$ & $(0.342)$ & $(0.329)$ \\
\hline \multirow[t]{2}{*}{ LMR_rig } & $1.137 * * *$ & $1.197 * * *$ & $1.159 * * *$ & $1.397 * * *$ & $1.233 * * *$ \\
\hline & $(0.390)$ & $(0.355)$ & $(0.364)$ & $(0.357)$ & $(0.351)$ \\
\hline \multirow[t]{2}{*}{$\log ($ Openness $) *$ LMR_rig } & $-0.338 * * *$ & $-0.343 * * *$ & $-0.335 * * *$ & $-0.391 * * *$ & $-0.351 * * *$ \\
\hline & $(0.0979)$ & $(0.0897)$ & $(0.0917)$ & $(0.0894)$ & $(0.0866)$ \\
\hline \multirow[t]{2}{*}{ Secondary Education Enrollment (Gross) } & $-0.0203 * * *$ & $-0.0226^{* * *}$ & $-0.0226 * * *$ & $-0.0238 * * *$ & $-0.0233 * * *$ \\
\hline & $(0.00188)$ & $(0.00199)$ & $(0.00199)$ & $(0.00208)$ & $(0.00210)$ \\
\hline \multirow[t]{2}{*}{$\log ($ Real Per Capita GDP) } & -0.0584 & 0.0333 & 0.0271 & 0.0468 & 0.0643 \\
\hline & $(0.0680)$ & $(0.0582)$ & $(0.0590)$ & $(0.0635)$ & $(0.0567)$ \\
\hline \multirow[t]{2}{*}{$\log ($ Urban Population Share $)$} & $0.437 * * *$ & $0.426 * * *$ & $0.431 * * *$ & $0.449 * * *$ & $0.433 * * *$ \\
\hline & $(0.0865)$ & $(0.0790)$ & $(0.0793)$ & $(0.0855)$ & $(0.0847)$ \\
\hline \multirow[t]{2}{*}{ Domestic Investisment } & & $-0.0117 * * *$ & $-0.0122 * * *$ & $-0.0112 * * *$ & $-0.0120 * * *$ \\
\hline & & $(0.00369)$ & $(0.00380)$ & $(0.00368)$ & $(0.00371)$ \\
\hline \multirow[t]{2}{*}{ Inflation, GDP deflator } & & & -0.00146 & -0.00110 & -0.00134 \\
\hline & & & $(0.00243)$ & $(0.00256)$ & $(0.00259)$ \\
\hline \multirow[t]{2}{*}{ Size Of Government } & & & & $0.0963 * * *$ & $0.0927 * * *$ \\
\hline & & & & $(0.0218)$ & $(0.0212)$ \\
\hline \multirow[t]{2}{*}{ Agriculture Added Value (\%) } & & & & & 0.00223 \\
\hline & & & & & $(0.00290)$ \\
\hline \multirow[t]{2}{*}{ Constant } & $-2.823^{*}$ & $-3.149 * *$ & $-3.006^{* *}$ & $-4.832 * * *$ & $-4.544 * * *$ \\
\hline & $(1.436)$ & $(1.276)$ & $(1.301)$ & $(1.336)$ & $(1.320)$ \\
\hline Country Fixed Effects & Yes & Yes & Yes & Yes & Yes \\
\hline Time Fixed Effects & Yest & Yes & Yes & Yes & Yes \\
\hline Observations & 333 & 333 & 333 & 333 & 331 \\
\hline R-squared & 0.257 & 0.348 & 0.348 & 0.341 & 0.354 \\
\hline Underindentification Test (Kleibergen-Paap Rk LM Statistic) & 41.52 & 40.51 & 40.86 & 38.33 & 39.92 \\
\hline Prob $>$ LM & 0 & 0 & 0 & 0 & 0 \\
\hline Weak Identification Test (Cragg-Donald Wald F Stat) & 11.81 & 12.24 & 12.16 & 11.96 & 11.34 \\
\hline Weak Identification Test(Kleibergen-Paap Rk Wald F Stat) & 11.87 & 12.92 & 12.66 & 12.69 & 12.37 \\
\hline Hansen_stat & 2.219 & 4.585 & 4.247 & 0.693 & 0.908 \\
\hline Hansen P_value & 0.330 & 0.101 & 0.120 & 0.707 & 0.635 \\
\hline \multicolumn{6}{|l|}{ Stock-Yogo weak ID test critical values: } \\
\hline 5\% Maximal IV Relative Bias & 9.53 & 9.53 & 9.53 & 9.53 & 9.53 \\
\hline $10 \%$ Maximal IV Relative Bias & 6.61 & 6.61 & 6.61 & 6.61 & 6.61 \\
\hline 20\% Maximal IV Relative Bias & 4.99 & 4.99 & 4.99 & 4.99 & 4.99 \\
\hline $30 \%$ Maximal IV Relative Bias & 4.30 & 4.30 & 4.30 & 4.30 & 4.30 \\
\hline
\end{tabular}

(Source) The authors.

Note. Values in brackets represent robust standard deviations; $* * *, * * *$ mean significant at a $1 \%, 5 \%$, and $10 \%$ level, respectively. 


\section{Impact on Young Women's Employment}

In this section, we focus solely on the employment of young women in SSA. Youth unemployment in SSA particularly affects young women. According to the African Development Bank (AfDB) (2016), among youth, gender differences are more pronounced in countries with high youth unemployment. According to the ILO, young women tend to be more disadvantaged in access to work and face worse working conditions than their male counterparts. What is the impact of trade openness and labor market regulation on the employment of young women in SSA? In contrast to previous regressions, we used the secondary education enrollment rate of young women rather than the secondary school enrollment rate of young people. Similarly, we added the fertility rate (that is, the number of births per woman) as an explanatory variable for young women's employment. A high fertility rate would be unfavorable to young women's employment because the more children young women have, the less likely they are to work. According to Brewster and Rindfuss (2000), the presence of children and their age influence women's participation in the paid labor market and, if they do participate, the nature of that participation. Indeed, women's work patterns are strongly related to changes in their family status (Ellingsæter \& Rønsen, 1996; Rindfuss et al., 1999; Rosenfeld, 1996). In SSA, many young women give birth early and have fewer incentives to seek employment. We expect the fertility rate to have a negative effect on young women's employment. The regression results are shown in Table 7. They reveal that the fertility rate negatively and significantly affected young women's employment. It also revealed a negative and statistically significant effect of trade openness on young women's employment. This result is not different from that found by Wamboye and Seguino (2015). They found that trade openness had a negative effect on women's employment in SSA. However, this effect was not significant. With regard to the rigidity of labor market regulation, it has a negative and significant effect contrary to previous results. However, this result does not contradict the World Bank (2009) statement that "The issue for developing countries is not whether or not to regulate, but what type and level of regulation is appropriate to achieve the best forms of protection for young people, who are generally vulnerable and insecure, without preventing formal firms from hiring" (p. 21). We found that the interactive term has a positive and statistically significant sign. This means that trade openness positively influences the employment of young women in rigid labor markets. Labor market institutions, especially unions in which men are overrepresented, and employment policies adopted by the state and employers have been a factor in promoting gender segregation in employment (Cheng \& Hsiung, 1998; Seguino, 2000). For example, gender-biased job offers might exclude women from certain well-paid, skilled jobs (Berik, 2005). Women and young women in SSA are often face discrimination in the labor market, and companies often encourage and benefit from this situation. Stricter labor market regulations in favor of women and young women would be more favorable to them. 
Table 7. Panel Regression of Young Women Employment on Trade Openness and Labor Market Regulation (IV with Results with Fixed Effects).

\begin{tabular}{|c|c|c|c|c|c|}
\hline \multicolumn{6}{|c|}{ Dependent Variable: $\log$ (Young Women Employment) } \\
\hline Variable & (1) & (2) & (3) & (4) & (5) \\
\hline \multirow[t]{2}{*}{$\log ($ Openness $)$} & $-0.588 * * *$ & $-0.534 * * *$ & $-0.508 * * *$ & $-0.459 * *$ & $-0.474 * *$ \\
\hline & $(0.193)$ & $(0.195)$ & $(0.194)$ & $(0.196)$ & $(0.191)$ \\
\hline \multirow[t]{2}{*}{ LMR_rig } & $-0.594 * * *$ & $-0.574 * * *$ & $-0.572 * * *$ & $-0.557 * * *$ & $-0.579 * * *$ \\
\hline & $(0.165)$ & $(0.174)$ & $(0.173)$ & $(0.174)$ & $(0.174)$ \\
\hline \multirow[t]{2}{*}{$\log ($ Openness $) * L M R \_r i g$} & $0.150 * * *$ & $0.143 * * *$ & $0.141 * * *$ & $0.136^{* * *}$ & $0.141 * * *$ \\
\hline & $(0.0415)$ & $(0.0439)$ & $(0.0437)$ & $(0.0439)$ & $(0.0435)$ \\
\hline \multirow[t]{2}{*}{ Secondary Education Enrollment (Gross), Young women } & $-0.00910^{* * *}$ & $-0.00993 * * *$ & $-0.00970 * * *$ & $-0.00888 * * *$ & $-0.00762 * * *$ \\
\hline & $(0.00266)$ & $(0.00259)$ & $(0.00259)$ & $(0.00258)$ & $(0.00264)$ \\
\hline \multirow[t]{2}{*}{$\log ($ Real Per Capita GDP $)$} & $-0.321 * * *$ & $-0.304 * * *$ & $-0.322 * * *$ & $-0.335 * * *$ & $-0.322 * * *$ \\
\hline & $(0.0608)$ & $(0.0623)$ & $(0.0631)$ & $(0.0623)$ & $(0.0572)$ \\
\hline \multirow[t]{2}{*}{$\log ($ Urban Population Share $)$} & $-0.198 * * *$ & $-0.199 * * *$ & $-0.190 * *$ & $-0.166^{* *}$ & $-0.134 *$ \\
\hline & $(0.0738)$ & $(0.0742)$ & $(0.0738)$ & $(0.0728)$ & $(0.0742)$ \\
\hline \multirow[t]{2}{*}{ Fertlity Rate (\%) } & $-0.141 * * *$ & $-0.136 * * *$ & $-0.134 * * *$ & $-0.118 * * *$ & $-0.137 * * *$ \\
\hline & $(0.0290)$ & $(0.0308)$ & $(0.0309)$ & $(0.0310)$ & $(0.0308)$ \\
\hline \multirow[t]{2}{*}{ Domestic Investisment } & & -0.00341 & -0.00423 & -0.00310 & -0.00338 \\
\hline & & $(0.00357)$ & $(0.00363)$ & $(0.00347)$ & $(0.00350)$ \\
\hline \multirow[t]{2}{*}{ Inflation, GDP deflator } & & & $-0.00298^{*}$ & $-0.00335^{*}$ & $-0.00420 * *$ \\
\hline & & & $(0.00166)$ & $(0.00173)$ & $(0.00179)$ \\
\hline \multirow[t]{2}{*}{ Size Of Government } & & & & $0.0749 * * *$ & $0.0611 * * *$ \\
\hline & & & & $(0.0202)$ & $(0.0204)$ \\
\hline \multirow[t]{2}{*}{ Agriculture Added Value (\%) } & & & & & $0.00773 * *$ \\
\hline & & & & & $(0.00324)$ \\
\hline \multirow[t]{2}{*}{ Constant } & $10.19 * * *$ & $9.941 * * *$ & $9.993 * * *$ & $9.202 * * *$ & $9.028 * * *$ \\
\hline & $(0.754)$ & $(0.756)$ & $(0.755)$ & $(0.799)$ & $(0.760)$ \\
\hline Country Fixed Effects & Yes & Yes & Yes & Yes & Yes \\
\hline Time Fixed Effects & Yest & Yes & Yes & Yes & Yes \\
\hline Observations & 300 & 298 & 298 & 298 & 298 \\
\hline R-squared & 0.597 & 0.603 & 0.606 & 0.621 & 0.633 \\
\hline Underindentification Test (Kleibergen-Paap Rk LM Statistic) & 31.12 & 35.34 & 35.51 & 35.63 & 36.68 \\
\hline Prob $>$ LM & $8.01 \mathrm{e}-07$ & $1.03 \mathrm{e}-07$ & $9.50 \mathrm{e}-08$ & $8.98 \mathrm{e}-08$ & $5.38 \mathrm{e}-08$ \\
\hline Weak Identification Test (Cragg-Donald Wald F Stat) & 200.3 & 176.9 & 176.1 & 175.1 & 174.4 \\
\hline Weak Identification Test (Kleibergen-Paap Rk Wald F Stat) & 90.97 & 76.29 & 75.21 & 75.01 & 76.04 \\
\hline Hansen_stat & 0.695 & 0.821 & 1.167 & 0.982 & 1.468 \\
\hline Hansen $P_{-}$value & 0.706 & 0.663 & 0.558 & 0.612 & 0.480 \\
\hline \multicolumn{6}{|l|}{ Stock-Yogo weak ID test critical values: } \\
\hline 5\% Maximal IV Relative Bias & 9.53 & 9.53 & 9.53 & 9.53 & 9.53 \\
\hline $10 \%$ Maximal IV Relative Bias & 6.61 & 6.61 & 6.61 & 6.61 & 6.61 \\
\hline 20\% Maximal IV Relative Bias & 4.99 & 4.99 & 4.99 & 4.99 & 4.99 \\
\hline 30\% Maximal IV Relative Bias & 4.30 & 4.30 & 4.30 & 4.30 & 4.30 \\
\hline
\end{tabular}

(Source) The authors.

Note. Values in brackets represent robust standard deviations; $* * *, * *,{ }^{*}$ mean significant at a $1 \%, 5 \%$, and $10 \%$ level, respectively. 


\section{Conclusion}

The objective of this study was to analyze the effect of trade openness and labor market regulation on youth employment in SSA. It covers a panel of 41 countries and covers the 2002-2017 period, a period dictated by the availability of data on labor market regulation taken from the Frazer Institute's EFW index. Unlike previous studies on the relationship between trade liberalization and youth employment (or unemployment), it integrated the interaction between trade liberalization and labor market regulation into its analysis. The estimates calculated using the pooled OLS followed by IV-2SLS provided the following results: trade openness and the rigidity of labor market regulation positively and significantly affected youth employment in SSA. More interestingly, trade openness negatively and significantly affected youth employment in more rigid labor markets in SSA. This result remains robust to several robustness tests. Thus, this study examined the case of young women's employment in SSA.

On the basis of our findings, we believe that trade liberalization policies in SSA should not be conducted without considering labor market regulation. African states must contribute to making labor markets more flexible. Indeed, for countries in the SSA region, greater openness to trade would be a necessary tool to address the problem of youth unemployment. Therefore, trade should be strengthened in SSA countries. Efforts should be made to expand trade, including the elimination of tariff and non-tariff barriers to trade since most African countries still face high levels of tariff and non-tariff barriers. Appropriate measures should be taken to liberalize the labor market to make it more flexible. These measures might relate to the legal and regulatory framework of countries' labor markets, including minimum wage regulations, laws prohibiting layoffs, severance requirements, and measurable regulatory restrictions on hiring and hours worked. However, labor market institutions must be safeguarded by employment protection policies to ensure that the foreign market does not benefit from the host country's labor market, and, more importantly, to ensure that labor market flexibility does not come at the expense of workers' rights to social security, health insurance, or other benefits.

Our research, despite its relevance, is not without limits. Some avenues for future research may be explored in the future with a view to further refining this work. For example, by analyzing the role of labor market regulation and trade openness in job creation, we did not consider the level of development of trading partners (developed countries and developing countries) or the nature of their labor markets (rigid or flexible). Moreover, it could not be determined which aspect(s) of labor market regulation would influence job creation more. Therefore, the effect of the different determinants of employment should not focus only on job creation, but try to differentiate between skilled and unskilled employment. More specific studies aligned with the realities of start-ups, small and medium enterprises (SMEs), large firms, and the public sector would be more relevant, as would a multi-sectoral analysis of the effects of the interaction 
between trade openness and labor market regulation. With the launch of the African continental free trade area, it would be interesting to study the effect of trade openness on unemployment in specific countries.

\section{References}

Acemoglu, D., \& Shimer, R. (1999). Efficient Unemployment Insurance. Journal of Political Economy, 107(5), 893-928.

Acemoglu, D., Johnson, S., \& Robinson, J. A. (2005). Institutions as a Fundamental Cause of Long-Run Growth. In Handbook of Economic Growth (pp. 385-472). Elsevier.

AfDB. (2016). Jobs for Youth in Africa: Strategy for Creating 25 Million Jobs and Equipping 50 Million Youth 2016-2025. Abidjan.

African Economic Outlook. (2012). Facilitate Labour Market Regulation to Promote Youth Employment. Retrieved November 26, 2012, http://www.africaneconomicoutlook.org/en/in-depth/youth_employment /facilitate-labour-market-regulation-to-promote-youth-employment/

Alexandre, F., Bação, P., Cerejeira, J., \& Portela, M. (2017). Exchange Rates, Employment and Labour Market Rigidity. The World Economy, 40(5), 993-1011.

Anyanwu, J. C. (2013). Characteristics and Macroeconomic Determinants of Youth Employment in Africa. African Development Review, 25(2), 107-129.

Anyanwu, J. C. (2014). Does Intra-African Trade Reduce Youth Unemployment in Africa? African Development Review, 26(2), 286-309.

Awad, A. (2019). Economic Globalisation and Youth Unemployment - Evidence from African countries. International Economic Journal, 33(2), 252-269.

Awad, A., \& Yussof, I. (2017). International Trade and Unemployment: Evidence from Selected ASEAN plus 3 Countries. DLSU Business \& Economics Review, 27(1), 1-12.

Bassanini, A., \& Duval, R. (2006). Employment Patterns in OECD Countries: Reassessing the Role of Policies and Institutions. In OECD Social, Employment and Migration Working Papers (No. 35; OECD Social, Employment and Migration Working Papers). OECD Publishing.

Berik, G. (2005). Growth with Gender Inequity: Another Look at East Asian Development. In G. Berik, A. Zammit, \& Y. van der M. Rodgers (Eds.), Social Justice and Gender Equality: Rethinking Development Strategies and Macroeconomic Policies. Routledge, New York.

Botero, J. C., Djankov, S., Porta, R. L., Lopez-de-Silanes, F., \& Shleifer, A. (2004). The Regulation of Labor. The Quarterly Journal of Economics, 119(4), 1339-1382.

Boulhol, H. (2009). Do capital market and trade liberalization trigger labor market deregulation? Journal of International Economics, 77(2), 223-233.

Boulhol, H. (2011). Unemployment and relative labor market institutions between trading partners. Journal of International Economics, 83(1), 83-91.

Brewster, K. L., \& Rindfuss, R. R. (2000). Fertility and Women's Employment in Industrialized Nations. 
Annual Review of Sociology, 26, 271-296.

Cheng, L. \& P. C. Hsiung. (1998). "Engendering the Economic Miracle: The Labour Market in the Asia-Pacific.” In G. Thompson (ed.) Economic Dynamism in the Asia-Pacific. London: Routledge. 112-136.

Clemens, M. A., \& Williamson, J. G. (2004). Why Did the Tariff-Growth Correlation Change after 1950 ? Journal of Economic Growth, 9(1), 5-46.

Davidson, C., \& Matusz, S. J. (2005). Trade and Turnover: Theory and Evidence. Review of International Economics, 13(5), 861-880.

Davis, D. (1998). Does European Unemployment Prop Up American Wages? National Labor Markets and Global Trade. American Economic Review, 88(3), 478-494.

Dutt, P., Mitra, D., \& Ranjan, P. (2009). International trade and unemployment: Theory and cross-national evidence. Journal of International Economics, 78(1), 32-44.

Ellingsæter, A. L., \& Rønsen, M. (1996). The Dual Strategy: Motherhood and the Work Contract in Scandinavia. European Journal of Population / Revue Européenne de Démographie, 12(3), 239-260.

Elmeskov, J., Martin, J. P., \& Scarpetta, S. (1998). Key lessons for labour market reforms: Evidence from OECD countries' experiences. Swedish Economic Policy Review, 5(2), Available at SSRN: https://ssm. com/abstract $=181273$

Felbermayr, G., Prat, J., \& Schmerer, H. J. (2011a). Globalization and labor market outcomes: Wage bargaining, search frictions, and firm heterogeneity. Journal of Economic Theory, 146(1), 39-73.

Felbermayr, G., Prat, J., \& Schmerer, H. J. (2011b). Trade and unemployment: What do the data say? European Economic Review, 55(6), 741-758.

Feldmann, H. (2003). Labor Market Regulation and Labor Market Performance: Evidence Based on Surveys among Senior Business Executives. Kyklos, 56(4), 509-540.

Feldmann, H. (2005). Labour Market Institutions and Labour Market Performance in Transition Countries. Post-Communist Economies, 17(1), 47-82.

Flaig, G., \& Rottmann, H. (2013). Labour market institutions and unemployment: An international panel data analysis. Empirica, 40(4), 635-654.

Frankel, J. A., \& Romer, D. H. (1999). Does Trade Cause Growth? American Economic Review, 89(3), 379-399.

Fugazza, M., Carrère, C., Olarreaga, M., \& Robert-Nicoud, F. (2014). Trade in unemployment (Research Study Series No. 64; Policy Issues in International Trade and Commodities). UNCTAD.

Goldberg, P., \& Pavcnik, N. (2003). The response of the informal sector to trade liberalization. Journal of Development Economics, 72(2), 463-496.

Gozgor, G. (2014). The impact of trade openness on the unemployment rate in G7 countries. The Journal of International Trade \& Economic Development, 23(7), 1018-1037.

Gozgor, G. (2017). The Impact of Globalization on the Structural Unemployment: An Empirical Reappraisal. International Economic Journal, 31(4), 471-489.

Hasan, R. (2001). The Impact of Trade and Labor Market Regulations on Employment and Wages: Evidence from Developing Countries. In Economics Study Area Working Papers (No. 32; Economics Study Area Working Papers). East-West Center, Economics Study Area. 
Heckman, J., \& Pages, C. (2004). Introduction to "Law and Employment: Lessons from Latin American and the Caribbean" (pp. 1-108) [NBER Chapters]. National Bureau of Economic Research, Inc. Helpman, Elhanan, \& Itskhoki, O. (2007). Labor Market Rigidities, Trade and Unemployment (Working Paper No. 13365; Working Paper Series). National Bureau of Economic Research.

Helpman, Elhanan, \& Itskhoki, O. (2010). Labour Market Rigidities, Trade and Unemployment. The Review of Economic Studies, 77(3), 1100-1137.

Iapadre, P. L. (2011). Trade and Employment in Italy (OECD Trade Policy Paper No. 126). OECD Publishing. Janiak, A. (2007). Does Trade Liberalization Lead to Unemployment? Theory and Some Evidence * [Mimeo]. Kabbani, N. (2019). Youth employment in the Middle East and North Africa: Revisiting and reframing the challenge. Retrieved from Brookings Doha Center website: https:/www.brookings.edu/research/yo uth-employment-in-the-middle-east-and-north-africa-revisiting-and-reframing-the-challenge/

Kim, J. (2011). The Effects of Trade on Unemployment: Evidence from 20 OECD countries. In Research Papers in Economics (2011:19; Research Papers in Economics). Stockholm University, Department of Economics.

Kiyota, K. (2011). Trade and Employment in Japan. In OECD Trade Policy Papers (No. 127; OECD Trade Policy Papers). OECD Publishing.

Klein, M., \& Weirowski, T. (2011). Trade and Unemployment in Germany: An Empirical Exploration and Some Theory (Global Financial Markets Working Paper Series No. 2011-24). Friedrich-SchillerUniversity Jena.

Krugman, P. (1995). Growing World Trade: Causes and Consequences. Brookings Papers on Economic Activity, 26(1, 25th Anniversary Issue), 327-377.

La Porta, R., Lopez-de-Silanes, F., Shleifer, A., \& Vishny, R. (1999). The quality of government. The Journal of Law, Economics, and Organization, 15(1), 222-279.

Madanizadeh, S. A., \& Pilvar, H. (2019). The impact of trade openness on labour force participation rate. Applied Economics, 51(24), 2654-2668.

Matusz, S. J. (1996). International Trade, the Division of Labor, and Unemployment. International Economic Review, 37(1), 71-84.

Moore, M. P., \& Ranjan, P. (2005). Globalisation vs Skill-Biased Technological Change: Implications for Unemployment and Wage Inequality. The Economic Journal, 115(503), 391-422.

Nickell, S., \& Layard, R. (1999). Chapter 46 Labor market institutions and economic performance. In Handbook of Labor Economics (pp. 3029-3084).

Nickell, S., Nunziata, L., \& Ochel, W. (2005). Unemployment in the OECD since the 1960s. What Do We Know? The Economic Journal, 115(500), 1-27.

Nugent, J. B. (2016). Does labor law reform offer an opportunity for reducing Arab youth unemployment? In Edward Sayre, \& Tarik Yousef (Eds.), Young generation awakening (pp. 188-203). New York, NY: Oxford University Press.

O'Higgins, N., \& Moscariello, V. (2017). Labour market institutions and youth labour markets: Minimum wages and youth employment revisited (EMPLOYMENT Working Paper No. 223). ILO.

Okun, A. M. (1962). Potential GNP : Its Measurement and Significance. Proceedings of the Business and Economics Statistics Section, American Statistical Association, 98-103. 
Pissarides, C. A. (2000). Equilibrium Unemployment Theory, 2nd Edition. In MIT Press Books (Vol. 1). The MIT Press.

Rindfuss, R. R., Cooksey, E. C., \& Sutterlin, R. L. (1999). Young Adult Occupational Achievement: Early Expectations Versus Behavioral Reality. Work and Occupations, 26(2), 220-263.

Rodrik, D. (2003). Globalisation, Social Conflict and Economic Growth. The World Economy, 21(2), 143-158.

Rosenfeld, R. A. (1996). Women's Work Histories. Population and Development Review, 22, 199-222.

Rovelli, R., \& Bruno, R. (2007). Labor market policies and outcomes: Cross country evidence for the EU-27 (Iza Discussion Paper Series, No. 3161).

Scarpetta, S. (1996). Assessing The Role of Labour Market Policies and Institutional Settings On Unemployment: A Cross-Country Study. OECD Economic Studies, 2(26), 43-82.

Seguino, S. (2000). Gender Inequality and Economic Growth: A Cross-Country Analysis. World Development, 28(7), 1211-1230.

Selwaness, I., \& Zaki, C. (2019). On the interaction between exports and labor market regulation: Evidence from the MENA countries. The Quarterly Review of Economics and Finance, 73, 24-33.

Şener, F. (2001). Schumpeterian unemployment, trade and wages. Journal of International Economics, 54(1), 119-148.

Stock, J. H., \& Yogo, M. (2005). Testing for Weak Instruments in Linear IV Regression. In D. W. K. Andrews \& J. H. Stock (Eds.), Identification and Inference for Econometric Models: Essays in Honor of Thomas Rothenberg (pp. 80-108). Cambridge University Press.

Tschirley, D., Haggblade, S., \& Reardon, T. (2013). Africa's emerging food system transformation. USAID.

UNCEA. (2017). Economic Report on Africa 2011: Urbanization and industrialization for Africa's transformation. Addis Ababa: United Nations Economic Commission for Africa (UNECA).

Viner, J. (1931). Cost Curves and Supply Curves. Zeitschrift Für Nationalökonomie / Journal of Economics, 3(1), 23-46.

Wamboye, E. F., \& Seguino, S. (2015). Gender Effects of Trade Openness in Sub-Saharan Africa. Feminist Economics, 21(3), 82-113.

Wang, F., Milner, C., \& Scheffel, J. (2018). Labour Market Reform, Firm-level Employment Adjustment and Trade Liberalisation [Technical Report].

World Bank. (2007). Doing Business 2008. Washington, DC.

World Bank. (2009). Global economic prospects 2009: Commodities at the crossroads. Washington, DC.

World Bank. (2012). Doing Business 2008. Washington, DC.

World Bank. (2018). Africa Human Capital Plan. Washington, DC. 


\section{Appendix}

Table A1. Ten Countries with High Levels of labor Market Flexibility vs. 10 Countries with Low Levels of Labor Market Flexibility (2002-2017 Average).

\begin{tabular}{|c|c|c|c|c|c|c|c|}
\hline \multicolumn{4}{|c|}{10 countries with high levels of labor market flexibility } & \multicolumn{4}{|c|}{10 countries with low levels of labor market flexibility } \\
\hline Country & LMR_flex & $\begin{array}{c}\text { Openness } \\
(\%)\end{array}$ & $\begin{array}{c}\text { Youth_Empl } \\
(\%)\end{array}$ & Country & LMR_flex & $\begin{array}{c}\text { Openness } \\
(\%)\end{array}$ & $\begin{array}{c}\text { Youth_Empl } \\
(\%)\end{array}$ \\
\hline Uganda & 8.60929012 & 41.7124786 & 46.595459 & Zimbabwe & 4.7960062 & 73.8559036 & 41.7630272 \\
\hline Gambia & 8.12445831 & 61.1481628 & 41.1315155 & Sudan & 4.71264696 & 30.7036591 & 51.7297516 \\
\hline Nigeria & 7.93453407 & 39.1790237 & 52.8590775 & Cabo Verde & 4.58578396 & 96.2957535 & 42.8891792 \\
\hline Burundi & 7.86741161 & 32.2472687 & 60.5062141 & Togo & 4.22975254 & 84.520546 & 50.370594 \\
\hline Eswatini & 7.7478714 & 130.693237 & 72.0787201 & African Central Republic & 4.08358002 & 40.5952187 & 71.3622437 \\
\hline Kenya & 7.66119623 & 53.3122864 & 31.2404366 & Senegal & 3.80732679 & 61.4579773 & 33.28586362 \\
\hline Rwanda & 7.65250826 & 38.3303528 & 31.4242935 & Angola & 3.68739629 & 112.954781 & 36.3782921 \\
\hline Namibia & 7.63794279 & 98.3662033 & 67.961525 & Niger & 3.42358661 & 50.362915 & 28.8052711 \\
\hline Gabon & 7.40267515 & 87.1946182 & 35.7221489 & Bissau Guinea & 3.31139278 & 50.5234947 & 50.7187576 \\
\hline Ethiopia & 7.29450941 & 40.350975 & 12.5670147 & Mozambique & 3.09051013 & 75.5764923 & 18.2260494 \\
\hline
\end{tabular}

(Source) The authors.

Note. $L M R \_$flex is a composite index consisting of six sub-indicators that measure the influence of hiring and minimum wage regulations, hiring and firing regulations, centralized collective bargaining, working hour regulations, mandatory costs of laying off workers, and conscription. The index measures the flexibility of labor market regulation; it is derived from the Frazer Institute's EFW index and is normalized from 0 to 10 with a higher value reflecting greater flexibility of labor market regulation. 